\title{
Stromal Neoplasm
}

National Cancer Institute

\section{Source}

National Cancer Institute. Stromal Neoplasm. NCI Thesaurus. Code C6781.

A benign or malignant mesenchymal neoplasm composed of stromal cells.

Representative examples include gastrointestinal stromal tumor, endometrial stromal sarcoma, and prostate stromal sarcoma. 